\title{
Landslide Inventory Using Knowledge Based Multi-sources Classification Time Series Mapping: A Case Study of Central Region of Kenya
}

\author{
Mercy Mwaniki ${ }^{1}$, Matthias Möller ${ }^{2}$ and Gerhard Schellmann ${ }^{1}$ \\ ${ }^{1,2}$ Bamberg University; Germany·mercimwaniki@yahoo.com \\ ${ }^{2}$ Beuth Hochschule für Technik, Berlin/Germany
}

Full paper double blind review

\begin{abstract}
Advances in classification using multispectral remote sensing imagery have gained increasing attention in solving environmental problems, and the management of disasters such as floods and landslides, due to their wide coverage and enabling ease of access in times of calamities. Multispectral data has facilitated the mapping of soils, land-cover, and structural geology, all of which are factors affecting landslide occurrence. The main aim of this research was to map landslide-affected areas using remote sensing techniques for the central region of Kenya, where landslide disasters are common occurrences. The study area has a highly rugged terrain, and rainfall has been the main trigger of recent landslide events. False colour composite (FCC), Principal Component Analysis (PCA), Independent Component Analysis (ICA), spectral indices in the form of Normalised Difference Index (NDI), and knowledge-based classification formed the methodology. PCA and ICA were performed on Landsat data sets, and the components with the most geologic information after factor loading analysis were chosen to be used in a colour composite. The blue component of the colour composite was a spectral index involving bands 7 and 3 for Landsat ETM+, or bands 7 and 4 for Landsat OLI. The FCC formed the inputs for knowledge based classification with the following 13 classes: runoff, extreme erosions, other erosions, landslide areas, highly erodible, stable, weathering rocks, agriculture, green, new forest regrowth areas, as well as clear, turbid, and salty water. Validation of the mapped landslide areas with field GPS locations of landslide affected areas showed that $66 \%$ and $62 \%$ of the points coincided well with landslide areas mapped in the years 2000 and 2014, respectively. The classification maps showed extreme erosions taking place along drainage channels and other erosions in agricultural areas; with highly eroble zones charchaterised by already weathered rocks or deposit area, while fluvial deposits mainly characterised runoff areas. Thus, landuse and rainfall processes play a major role in landslide processes in the study area.
\end{abstract}

\section{$1 \quad$ Introduction}

Advances in classification in remote sensing to applications in environment, disaster monitoring, and management, have attracted attention in recent research including landslide mapping. Detection of landslides through remote sensing intepretation techniques requires

GI_Forum - Journal for Geographic Information Science, 1-2015.

(c) Herbert Wichmann Verlag, VDE VERLAG GMBH, Berlin/Offenbach. ISBN 978-3-87907-558-4.

(C) ÖAW Verlag, Wien. ISSN 2308-1708, doi:10.1553/giscience2015s209. 
image processing methods, which enhance recogntion leading to their classification. Landslide recognition and mapping is facilitated by the difference in spectral characteristics, contrast from the sorrounding areas, and their morphological expression (MANTOVANI et al. 1996). Therefore, multispectral remote sensing data have gained more utility in landslide mapping and monitoring, owing to their better discrimination through image enhancement techniques. The main objective of this research was to map landslide areas using remote sensing technologies, in order to create a landslide inventory for rainfall induced landslides in the central region of Kenya. In the past, the study area has experienced landslides triggerred by rainfall, but little has been done to map the affected areas, although some studies (NGECU \& ICHANG'I 1998, NGECU et al. 2004) recorded the incidences and investigated possible causes - among them heavy rainfall triggers and geology. Little has been done scientifically to link the landslides and the controlling factors in this study area. Creating a landslide inventory will boost landslide susceptibility studies as a second step in this research.

The successful implementation of a classification system requires suitable variables be used in the classification (LU \& WENG 2007). Such variables may include vegetation indices, feature space transformed images, band ratios, topographical data, textural data, multitemporal images, multisensor data, and spectral signatures. The ability to incoporate ancillary data in a classification system using expert rules has greately reduced spectral confusion among landcover classes in a complex biophysical environment. For example, FRANKLIN et al. (1994) and MEYER et al. (1993) improved land-cover classification accuracy by incorporating topographic data in mountainous regions, since land cover distribution relates to relief and elevation, while MYINT (2001) incorporated texture analysis in an urban land use classification. The implementation of such classifications is enabled through knowledge based classification techniques (AMARSAIKHAN \& DOUGLAS 2004), decision rules, and artificial neural networks.

Research based on improving image classification, such as that conducted by JENSEN (1996) and LANDGREBE (2003), has empasized the selection of optimal spectral bands for use in classifications. Multivariate analysis techniques of PCA and ICA work by transforming and reducing multispectral axes into orthogonal components, which preserve as much of the desired information as possible. The use of tranformed feature space data (e.g. minimum noise fraction, tassel cap, PCA, ICA) and feature extraction techniques can greatly boost a classification, by resulting in well differentiated landcover classes. For Example; DI PRINZIO et al. (2011) incorporated PCA and ICA to improve unsupervised neural classification (SOM) for a catchment elements classification.

\section{Remote Sensing of Disturbed Vegetation}

Landslides are localized phenomena, which reflect specific conditions of site stability, where vegetation cover contributes to root cohesion and thus influence slope stability (ROERING et al. 2003, SCHMIDT et al. 2001). Applications involving landsliding or risk mapping require the identification of disturbed vegetation or loss of vegetation, which are then related to landslide incidences. For example, MEYER et al. (2001) managed to relate how fire and storm events acceleralated soil erosion and shallow landsliding in Idaho batholith. Vegetation indices provide a measure of the protective role of vegetation, in places where 
vegetation plays a crucial role in preventing soil erosion (DEWITTE et al. 2012). The amount of fuel moisture influences burning efficiency (CECCATO et al. 2002).

Spectral indicies of vegetation utilise the near infrared and visible (red) bands to distinguish healthy vegetation (high reflectance in the near infrared region) from diseased, burnt, or dying vegetation, which have decreased reflectance in the NIR region (JENSEN 2007). This provides the basis for vegetation monitoring, where the vegetation indices are designed to assess the contribution of green vegetation content to multispectral observations. BANNARI et al. (1995) have summarised the commonly used vegetation indices, usually presenting a complex mixture of vegetation, soil brightness, environmental effects, shadow, soil colour, and moisture. CECCATO et al. (2002) described a methodology of designing a spectral index in the solar spectrum domain and the limitations and robustness of such an index. Spectral vegetation indices often take the form of a NDI, expressed as equation 1 (BRIGHT et al. 2010) or ratio form. Examples are: NDVI (TUCKER 1979), NDWI (GAO 1996), NBR (EPTING et al. 2005), PRI (BRIGHT et al. 2010).

$$
N D I=\frac{\lambda_{i}-\lambda_{j}}{\lambda_{i}+\lambda_{j}} \quad \text { where } \lambda \text { is the measured reflectance at bands } i \text { and } j
$$

Landsat imagery has found major applications in developing spectral indices, not only for burnt vegetation (e.g. PATTERSON \& YOOL 1998, ROGAN \& YOOL 2001), but also for mineral mapping (NIELD et al. 2007), soil applications (e.g. BOETTINGER et al. 2008), and band ratios for geological applications (ALI et al. 2012, KAVAK 2005, SABINS 1999). VOHORA \& DONOGHUE (2004) developed a Normalised Difference Mid infrared spectral index (NDMIDIR) using Landsat bands 7 and 4 to map areas of disturbed vegetation (including stressed forests or forest fires). NDMIDIR and NDVI were produced using equations 2 and 3, where NDMIDIR successfully indentified landslide scars and forest fire scars compared to NDVI, which only depicted areas with healthy vegetation.

$$
\text { NDMIDIR }=\frac{\text { TM4 }- \text { TM7 }}{\text { TM4+TM7 }}
$$

$$
\mathrm{NDVI}=\frac{\mathrm{TM} 4-\mathrm{TM} 3}{\mathrm{TM} 4+\mathrm{TM} 3}
$$

Image colour enhancement techniques, involving processed images or multispectral data provide a powerful means of visualising landslide features. For example, MoNDINI et al. (2011) used an FCC comprising ( $\delta$ NDVI, IC4, PC4) to visualise landslide areas triggered by typhoons, while FERNÁNDEZ et al. (2008) used several FCCs comprising bands from the visible, NIR, and SWIR regions to show landslide scarps and lithological changes related to landslides. Landslide mapping utilising spectral indices such as NDVI (e.g. TSAI et al. 2010) or NDMIDIR (e.g. ZHANG et al. 2005) had similar enhancement levels as the use of FCC (FERNÁNDEZ et al. 2008). WHITWORTH et al. (2005) used FCC image enhancement using airborne photography imagery and investigated the effect of texture enhancement in indentifying landslides, where the classification successfully differentiated landslide areas from stable slopes. PCA techniques as an image enhancement method has also been used in landslide mapping (e.g. PETLEY et al. 2002, RAWASHDEH et al. 2006). PC2 was used to map burn servereity by (PATTERSON \& YOOL 1998, ROGAN \& CHEN 2004).

Research presented here has modified NDMIDIR spectral index developed by VOHORA \& DonOGHUE (2004), to NDMIDR for landsat TM/ETM+ and NDMIDIR for Landsat OLI. These have been used in a false colour composite involving independent and principal component as the basis of landslide mapping. The modification was informed by usage of 
bands in CAMPBELL (1996), where Landsat TM bands 2 and 4 are highly reflective zones for vegetation, while band 3 is helpful for discriminating soil from vegetation due to the high absorbency effect of vegetation. Bands 5 and 7 are best suited for rock and soil studies, since soil has a high absorption in band 7, and a high reflectance in band 5 .

\section{Methodology}

\subsection{Study Area}

The study area is located in the central region of Kenya and ranges in longitude from $35^{\circ} 34^{\prime} 00^{\prime \prime} \mathrm{E}$ to $38^{\circ} 15^{\prime} 00^{\prime \prime} \mathrm{E}$, and latitudes $0^{\circ} 53^{\prime} 00^{\prime \prime} \mathrm{N}$ to $2^{\circ} 10^{\prime} 00^{\prime \prime} \mathrm{S}$ (Figure 1). It has a highly rugged mountainous terrain, with deep incised river valleys and narrow ridges, and altitude varying from $450 \mathrm{~m}$ to $5100 \mathrm{~m}$ above mean sea level. Deep weathering of rocks is attributed to soil formation where NGECU et al. (2004) noted 3 major types of soils: nitosols, andosols, and cambisol. Land use and land cover are mainly dependent on climatic characteristics, whereby mainly highland to savanna climate is prevalent in the region, thus forest, agriculture and settlement are the most prevalent land use and land covers. Landslides triggered by rainfall are also a major threat on the south eastern slopes of the Aberdare mountain ranges, as reported in MwANIKI et al. (2011) and NGECU \& ICHANG'I (1998).

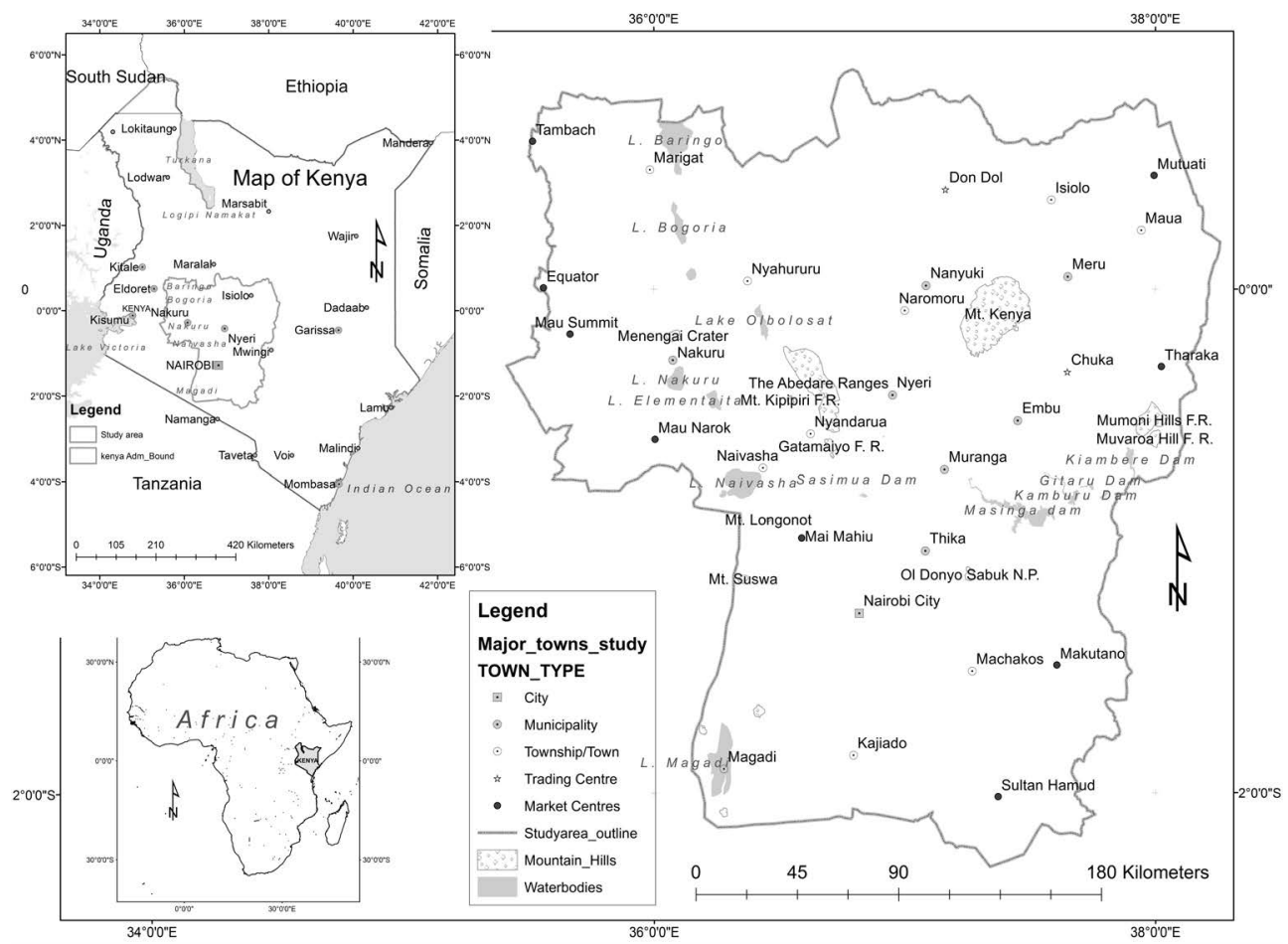

Fig. 1: Map of the Study Area 


\subsection{Data Description}

Landsat 7, ETM+ (year 2000) and Landsat 8, OLI (year 2014), scenes p168r060, p168r061, and p169r060 nearly free of cloud cover, were downloaded from the USGS web page, and pre-processed individually for each year by layerstacking, mosaicking, and subsetting. Atmospheric effects were reduced using the Landsat 5 TM haze reduction method in Erdas Imagine, since path 169 and path 168 of Landsat imagery were taken about three weeks apart, but in the same season. For Landsat 8 , band 9 was subtracted from all the bands to improve the image contrast. STRM DEM, $25 \mathrm{~m}$ resolution for the same scenes was also downloaded from the USGS site, mosaicked, and subset with the study area outline.

\subsection{Image Enhancement and Knowledge Based Classification}

Image enhancement involved principal and independent component analysis, formation of a spectral index, which enhances de-vegetated and landslide areas, and their combination in a false colour composite. A false colour composite involving the independent and principal component with the highest contribution from bands 5,7 and 3, and a spectral index given by equation 6 and 7 for landsat 5/7 and 8 respectively, was the basis for landslide areas identification.

$$
N D M I D R=\frac{T M_{7}-T M_{3}}{T M_{7}+T M_{3}} \quad \text { (6) } \quad \text { or } \quad N D M I D I R=\frac{O L I_{7}-O L I_{4}}{O L I 7+O L I_{4}}
$$

NDMIDR was compared to NDVI visually, where NDMIDR was found to have enhanced geological features, while NDVI highlighted only vegetation greenness content. FERNÁNDEZ et al. (2008) recommended the combination of textural analysis and digital classification in order to identify landslide features or mobilized areas. Therefore, NDMIDR spectral index provided some textural characteristics and was used in the FCC to visualise landslide areas. The input variables to the knowledge based classification were: principal component, independent component, normalised difference index involving bands 7 and 3 for Landsat 5/7, and bands 4 and 7 for Landsat 8 , slope and elevation. The FCC combinations for the years 2000 and 2014 are presented in figure 2 .
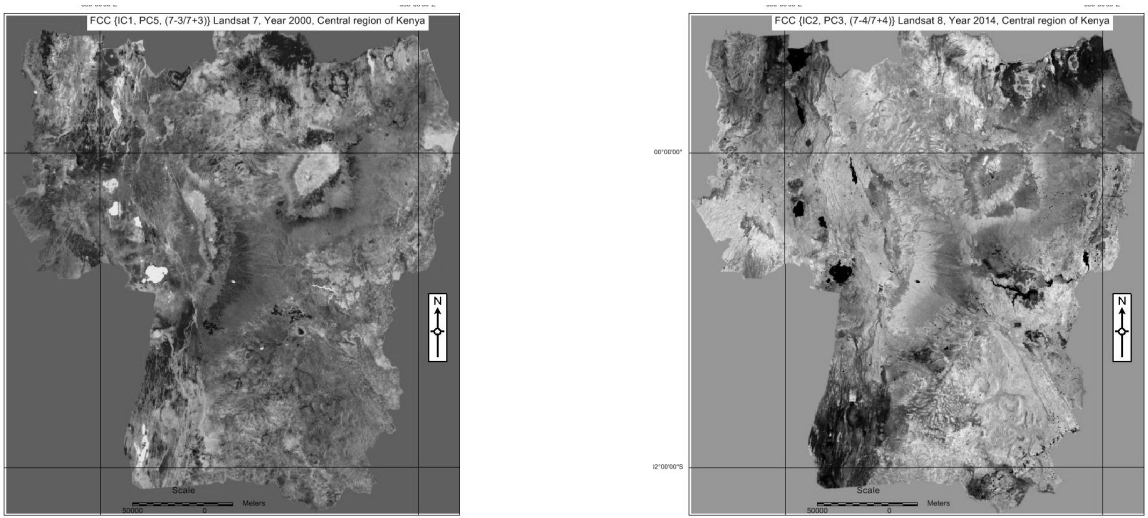

Fig. 2: FCC combinations involving IC, PC and Spectral Index with bands $7 \& 3 / 4$ 
The expert classification rules were formed using one of the methods stated by (HODGSON et al. 2003), where rules could be generated from observed data using cognitive methods. Each false colour combination was first visually examined, followed by assigning major colours to a particular class, after which the histogram of each layer was examined, and the highest and lowest values noted. For each class, the file pixel values range was then examined, and set in the knowledge based file by inquiring at various points with the same colour. A trial run classification was performed after which the rules and classes were refined further until all the values in each layer of the FCC had been assigned a class. The classification rules for this study are as presented in the tables 1 and 2 below. Elevation and slope variables were used to restrict crop and water covers to $<3200 \mathrm{~m}$ and $<15$ degrees, respectively. A total of 13 classes, namely: runoff, extreme erosions, other erosions, landslide areas, highly erodible, stable, weathering rocks, agriculture areas, green, new forest regrowth, rivers/clear water, turbid water, and salty water were identified and mapped as shown in figures 3 and 4 in the next section.

Table 1: 2000 classification rules

\begin{tabular}{|c|c|c|c|c|c|c|}
\hline \multirow[b]{2}{*}{ Classes } & \multicolumn{3}{|c|}{ Variables (classification, year 2000) } & \multicolumn{3}{|c|}{ Variables (classification, year 2014) } \\
\hline & IC1 & PC5 & $\begin{array}{c}\text { Ratio } \\
(7-3 / 7+3) \\
\end{array}$ & IC2 & PC3 & $\begin{array}{c}\text { Ratio } \\
(7-4 / 7+4) \\
\end{array}$ \\
\hline \multirow[t]{2}{*}{ Runoff } & $-0.25-0.350$ & $<-1.5$ & $0--0.200$ & $0-3$ & $<-800$ & $-0.4-0.200$ \\
\hline & $0.750-1$ & $<-4.5$ & $0-0.050$ & & & \\
\hline $\begin{array}{l}\text { Extreme } \\
\text { erosions }\end{array}$ & $1.25-6$ & $6--1.5$ & $-0.700-0.015$ & $0-3$ & $<0$ & $0.150-0.400$ \\
\hline Other erosions & $0.750-6$ & $-1.5--4.5$ & $0.075--0.450$ & $>3$ & $>500$ & $>0.2$ \\
\hline Landslide & $<-0.110$ & $<-1.5$ & $<-0.035$ & $<1.2$ & $<1250$ & $>0.260$ \\
\hline Highly erodible & $<0.750$ & $6-0.5$ & $\geq 0.095$ & $>3$ & $<500$ & $-0.3-0.4$ \\
\hline \multirow[t]{2}{*}{ Stable } & $-0.114-0.75$ & $-1.5--7$ & $-0.06-0.099$ & $-2-1.2$ & $-300-1250$ & $>0.275$ \\
\hline & $0.750-1.8$ & $0.75-6$ & $0.050-0.250$ & $-2-0$ & $-650--300$ & $0.150-0.300$ \\
\hline \multirow[t]{4}{*}{ rocks } & $<0.750$ & $\geq 6.5$ & $\geq 0.075$ & $-3-0$ & $-3500--650$ & $0.150-0.900$ \\
\hline & $-2-3$ & $\geq 9.2$ & $0.200--0.300$ & $>3$ & $0-600$ & $0.1-0.4$ \\
\hline & $-1.2-4.5$ & $6-9.2$ & $0-0.250$ & $<0$ & $-3000--1900$ & $<-0.3$ \\
\hline & $1.5-6.0$ & $6-20$ & $-0.250--0.035$ & $-3-0.3$ & $-3500--650$ & $0.150-0.900$ \\
\hline \multirow[t]{2}{*}{ crops } & $-1.75-0.75$ & $0.3-6.5$ & $0.050-0.095$ & $1.2-3$ & $-800-3000$ & $-0.3-0.450$ \\
\hline & $-1.5--1.5$ & $0.3-2.5$ & $-0.06-0.050$ & $>3$ & $500-3000$ & $-0.2-0.2$ \\
\hline \multirow[t]{3}{*}{ Green } & $-0.25-1.25$ & $0.3-2.5$ & $-0.370--0.060$ & $-2.7-1.2$ & $-1900--300$ & $-0.300-0.150$ \\
\hline & $-1-1.4$ & $2.5-6.0$ & $-0.370-0.050$ & & & \\
\hline & $-0.2-1.5$ & $6.0-9.2$ & $-0.370-0$ & & & \\
\hline $\begin{array}{l}\text { New forest } \\
\text { regrowth }\end{array}$ & $\leq-0.250$ & $<0.3$ & $\geq 0$ & $-0.8-1.2$ & $-300-1000$ & $-0.100-0.300$ \\
\hline River waters & $1-6$ & $6-20$ & $<-0.250$ & $<0$ & $<-3000$ & $-0.8--0.3$ \\
\hline \multirow[t]{2}{*}{ Turbid water } & $1-6$ & $<6$ & $<-0.300$ & $<0$ & $<-3000$ & $<-0.8$ \\
\hline & $>6$ & $<0$ & $<0$ & & & \\
\hline \multirow[t]{2}{*}{ Salty water } & $>1$ & $>20$ & $<0$ & $>0$ & $<-1500$ & $<-0.2$ \\
\hline & $>6$ & $0-20$ & $>0$ & & & \\
\hline
\end{tabular}

\section{$4 \quad$ Result and Discussion}

The classification results after running the classification rules in tables 1 and 2 are presented in figures 3 and 4, where landslide areas were mapped amongst other vegetated areas (green forest, new forest regrowth, agricultural crops), water or non-vegetated covers which 
were associated with eroded areas (extreme erosions, other erosions,), depositional areas (runoff, highly erodible, stable), or rocks. The landslide mapping results between the years 2000 versus 2014 are analysed, using table 3 for comparison. The classification may serve to explain the contribution of land use and rainfall to landsliding, where depositional and water areas had increased, whereas eroded, exposed rocks, as well as landslide areas and vegetation had decreased comparing the years 2000 and 2014 (table 3). The observations are consistent with the heavy El-Niño rains falling in the period October 1997 to May 1998, and whose devastating effects are recorded by NGECU \& MATHU (1999). Consequently, the classification for the year 2000 had more landslide areas compared to the year 2014. Deposit areas and water cover are, however, on the increase compared to vegetated areas.

Landsat SWIR bands (5 and 7) are sensitive to canopy moisture content (VOHORA \& DonOGHUE 2004). Therefore, the use of band 7 in the NDMIDR spectral index together with band 3 captured vegetation moisture properties and differentiated soil reflectance in vegetated areas, thereby overcoming the challenge of using the NDVI spectral index, which emphasized only vegetated areas. Also, Landsat band 7, which is predominantly used as a geology band, contributed to the NDMIR spectral index by incorporating geology aspects, and provided texture details unlike the NDVI, which is very smooth. The SWIR region is sensitive to clay bearing minerals, while the VNIR region provides some information about iron oxides (ABDEEN \& HASSAN 2009). Therefore, the NDMIR highlighted clayey areas and possible deposit areas. A colour image comprising IC, PC, and NDMIR spectral indices best visualized landslide areas, where the components allowing maximum separation and containing the highest contribution from bands 5, 7, and 3 were chosen. Principal component and independent canonical analysis, which are feature extraction and data reduction methods (JENSEN 1996), were used to extract pertinent information from Landsat bands 1-5 $\& 7$.

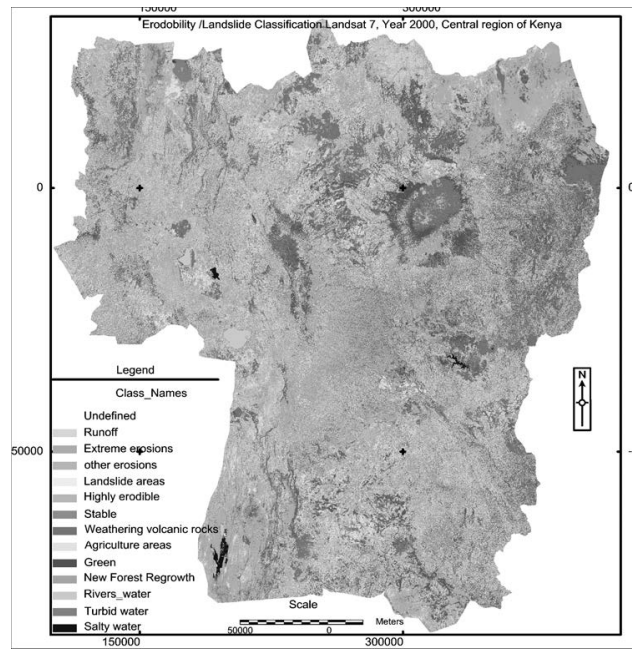

Fig. 3: Erodibility/landslide classification \{Inputs: IC1, PC5, band ratio index $\{7-3 / 7+3\}$

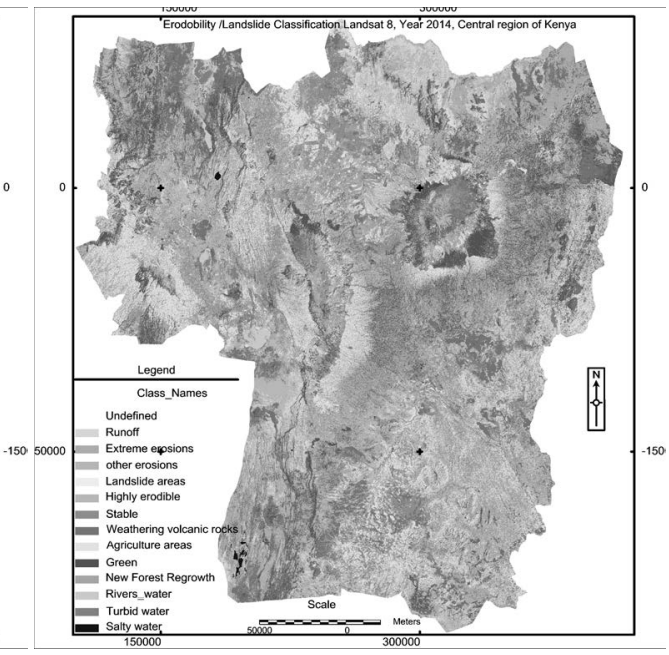

Fig. 4: $\quad$ Inputs: IC2, PC3 
Table 3: Representation of landslide areas in percentage in comparison to other covers

\begin{tabular}{|c|c|c|c|c|c|}
\hline & Classes & 2000 & & 2014 & \\
\hline landslide areas & landslide areas & 0.25 & & 0.18 & \\
\hline \multirow[t]{2}{*}{ Eroded areas } & extreme erosion & 8.22 & \multirow{2}{*}{16.41} & 8.2 & \multirow{2}{*}{9.63} \\
\hline & other erosion & 8.19 & & 1.43 & \\
\hline \multirow[t]{3}{*}{ Depositional areas } & runoff & 4.09 & \multirow{3}{*}{17.43} & 1.78 & \multirow{3}{*}{40.04} \\
\hline & Highly erodible & 5.93 & & 20.73 & \\
\hline & stable & 7.41 & & 17.53 & \\
\hline rocks & weathering volcanic rocks & 10.54 & & 9.65 & \\
\hline \multirow[t]{3}{*}{ Vegetated areas } & agriculture areas & 27.26 & & 14.82 & \\
\hline & Ever green forest & 17.48 & \multirow{2}{*}{27.30} & 10.26 & \multirow{2}{*}{24.68} \\
\hline & new forest regrowth & 9.82 & & 14.42 & \\
\hline \multirow[t]{4}{*}{ Water bodies } & clear & 0.38 & \multirow{3}{*}{0.81} & 0.56 & \multirow{3}{*}{0.99} \\
\hline & turbid & 0.22 & & 0.12 & \\
\hline & salty & 0.21 & & 0.31 & \\
\hline & & 100 & & 99.99 & \\
\hline
\end{tabular}

Landslides mapped through classification were verified in comparison with sample GPS points, previously mapped in a field study over the study area. $66 \%$ and $62 \%$ of the points coincided well with landslide areas mapped in the years 2000 and 2014, respectively. This is because landslide rehabilation takes place as soon as the rain period is over, thereby making it difficult to map some areas by the remote sensing method described in this study. Instead, information from the local inhabitants was found useful in verifying the landuse activities (deforestation, cultivation on very steep slopes, lack of proper water channels), thereby explaining why some GPS points coincided with eroded or deposit areas in the classification maps.

\section{Conclusions and Recommendations}

The colour image comprising (IC, PC, NDMIDR in R, G, B) displayed important surface characteristics of lithology, soil moisture, and vegetation canopy moisture, which facilitated the classification mapping, differentiating between areas characterised by landslides, erosion, deposits, stable, runoff, exposed weathering rocks, vegetated areas, and water cover. Specifically, the use of a spectral index involving bands 7 and 3 for Landsat TM/ETM+, and bands 7 and 4 for Landsat OLI as a Normalised Difference Index helped to emphasize moisture content in vegetation and soils, while the use of PC and IC components captured the lithology components. The classification achieved the objective of mapping landslideaffected areas in the years 2000 and 2014, by distinguishing, among other covers, mainly vegetated, non-vegetated or water areas. The classification may serve to explain the contribution of land use and rainfall to landsliding, whereby the classification for the year 2000 captured the devastating effects of El-Niño rains (October 1997 to May 1998), while the classification for 2014 captured decreasing vegetation and increasing depositional areas. 
Field observations showed rehabiliation taking place in some affected areas; thus it was not possible to map such areas as landslide areas in the classification method.

The classification maps showed extreme erosions taking place along drainage channels, other erosions taking place in agricultural areas, highly eroble zones with already weathered rocks or deposit area, while runoff was mainly fluvial deposits. The results obtained are going to form the basis for landslise suceptibility mapping for the study area, considering other landslide factors such as slope, closeness to drainage and roads, changes in landuse, geology, rainfall, soil properties, and aspect.

\section{Acknowledgement}

We thank Nathan Agutu and all our anonymous reviewers for their contribution to improve the quality of this paper. We acknowledge support from USGS website for the Landsat imagery and thank DAAD/NACOSTI for their continued support for post graduate research study grant no A/12/94131.

\section{References}

AbDeEn, M. M. \& HASSAN, S. M. (2009), Utilisation of Spectral Signature and PCA, of TERRA ASTER images for exploring new sites of building sand and gravels, NW Gulf of Suez, Egypt.

Ali, E. A., El Khidir, S. O., Babikir, A. A. \& Abdelrahnam, E. M. (2012), Landsat ETM+7 Digital Image Processing Techniques for Lithological and Structural Lineament Enhancement: Case Study Around Abidiya Area, Sudan. Open Remote Sens. J., 5, 83-89.

Amarsaikhan, D. \& Douglas, T. (2004), Data fusion and multisource image classification. Int. J. Remote Sens., 25, 3529-3539.

Bannari, A., Morin, D., Bonn, F. \& Huete, A. R. (1995), A review of vegetation indices. Remote Sens. Rev., 13, 95-120.

Boettinger, J. L., Ramsey, R. D., Bodily, J. M., Cole, N. J., Kienast-Brown, S., NiEld, S. J., SAunders, A. M., \& Stum, A. K. (2008), Landsat Spectral Data for Digital Soil Mapping. In: HarteminK, A. E., McBratney, A. \& MendonçA-Santos, M. DE L. (Eds.), Digital Soil Mapping with Limited Data. Springer, Netherlands Dordrecht, 193-202.

Bright, A., HAMMELl, R. \& AARDT, J. VAN (2010), Identification of spectral Indicators in Vegetation Disturbance. Chester F. Carlson Centre for Imaging Science, Rochester Institute of Technology.

CAMPBell, J. B. (1996), Introduction to remote sensing. Guilford Press, New York, NY.

Ceccato, P., Gobron, N., Flasse, S., Pinty, B. \&Tarantola, S. (2002 ), Designing a spectral index to estimate vegetation water content from RS data: Part 1. Remote Sens. Environ., 82, 188-197.

Dewitte, O., Jones, A., Elbelrhiti, H., Horion, S. \& Montanarella, L. (2012), Satellite remote sensing for soil mapping in Africa: An overview. Prog. Phys. Geogr., 36, 514-538. 
Epting, J., Verbyla, D. \& Sorbel, B. (2005), Evaluation of remotely sensed indices for assessing burn severity in interior Alaska using Landsat TM and ETM+. Remote Sens. Environ., 96, 328-339.

Fernández, T., JimÉnez, J., Fernández, P., El Hamdouni, R., CARdenal, F. J., DelgaDO, J., IRIGARAY, C. \& CHACÓN, J. (2008), Automatic detection of landslide features with RS techniques in the betic cordilleras (Granada, Spain). Int. Arch. Photogramm. Remote Sens. Spat. Inf. Sci., 37, 351-356.

Franklin, S. E., CONNERY, D. R. \& Williams, J. A. (1994), Classification of alpine vegetation using Landsat Thematic Mapper, SPOT HRV and DEM data. Can. J. Remote Sens., 20, 49-56.

GAO, B. (1996), NDWI - A normalized difference water index for remote sensing of vegetation liquid water from space. Remote Sens. Environ., 58, 257-266.

Hodgson, M. E., Jensen, J. R., Tullis, J. A., Riordan, K. D. \& ArCher, C. M. (2003), Synergistic Use of Lidar and Color Aerial Photography for Mapping Urban Parcel Imperviousness. Photogramm. Eng. Remote Sens., 69, 973-980.

JENSEN, J. R. (1996 ), Introductory digital image processing: a remote sensing perspective. Prentice Hall, Upper Saddle River, N.J.

JEnsen, J. R. (2007), Remote Sensing of vegetation. In Remote Sensing of the Environment: An Earth Resource Perspective. Pearson Prentice Hall, Upper Saddle River, NJ.

KAVAK, K. S. (2005), Determination of palaeotectonic and neotectonic features around the Menderes Massif and the Gediz Graben (West. Turkey) using Landsat TM image. Int. J. Remote Sens., 26, 59-78.

LANDGREBE, D. A. (2003), Signal theory methods in multispectral remote sensing. Wiley, Hoboken, New Jersey.

LU, D. \& WENG, Q. (2007), A survey of image classification methods and techniques for improving classification performance. Int. J. Remote Sens., 28, 823-870.

MAntovani, F., Soeters, R. \& VAN Westen, C. J. (1996), Remote sensing techniques for landslide studies and hazard zonation in Europe. Geomorphology, 15, 213-225.

Meyer, G. A., Pierce, J. L., Wood, S. H. \& Jull, A. J. T. (2001 ), Fire, storms, and erosional events in the Idaho batholith. Hydrol. Process., 15, 3025-3038.

Meyer, P., ItTen, K. I., Kellenberger, T., SAndmeier, S. \& SAndmeier, R. (1993), Radiometric corrections of topographically induced effects on Landsat TM data in alpine environment. ISPRS Int. J. Photogramm. Remote Sens., 48, 17-28.

Mondini, A. C., Chang, K.-T. \& YIN, H.-Y. (2011), Combining multiple change detection indices for mapping landslides triggered by typhoons. Geomorphology, 134, 440-451.

Mwaniki, M. W., Ngigi, T. G. \& Waithaka, E. H. (2011), Rainfall Induced Landslide Probability Mapping for Central Province. In Fourth Intern. Summer School and Conf., (JKUAT, Kenya: Publications of AGSE Karlsruhe, Germany), 203-213.

MYINT, S. W. (2001), A Robust Texture Analysis and Classification Approach for Urban Land Use and Land Cover Feature Discrimination. Geocarto Int., 16, 29-40.

NgecU, M. W. \& ICHANG'I, D. W. (1998), The environmental impact of landslides on the population living on the eastern footslopes of the Aberdare ranges in Kenya: a case study of Maringa Village landslide. Environ. Geol., 38, 259-264.

Ngecu, W. M. \& MAthu, E. M. (1999), The El-Nino- triggered landslides and their socioeconomic impact on Kenya. Eng. Geol., 38, 277-285.

Ngecu, W. M., Nyamai, C. M. \& ERIMA, G. (2004), The extent and significance of massmovements in Eastern Africa: case studies of some major landslides in Uganda and Kenya. Environ. Geol., 46, 1123-1133. 
Nield, S. J., Boettinger, J. L. \& Ramsey, R. D. (2007), Digitally Mapping Gypsic and Natric Soil Areas Using Landsat ETM Data. Soil Sci. Soc. Am. J., 71, 245-252.

PAtTerson, M. W. \& Yool, S. R. (1998), Mapping Fire-Induced Vegetation Mortality Using Landsat Thematic Mapper Data. Remote Sens. Environ., 65, 132-142.

Petley, D. N., Crick, W. D. \& Hart, A. B. (2002), The use of satellite imagery in landslide studies in high mountain area. In: ACRS 2002, Kathmandu, Nepal.

Di PRINZIO, M., CASTEllarin, A. \& TOTH, E. (2011), Data-driven catchment classification: application to the pub problem. Hydrol. Earth Syst. Sci., 15, 1921-1935.

Rawashdeh, S. A., Saleh, B. \& Hamzah, M. (2006), The use of Remote Sensing Technology in geological Investigation and mineral Detection in El Azraq-Jordan. Cybergeo Eur. J. Geogr. Syst. Model. Geostat.

Roering, J. J., Schmidt, K. M., Stock, J. D., Dietrich, W. E. \& Montgomery, D. R. (2003), Shallow landsliding, root reinforcement, and the spatial distribution of trees in the Oregon Coast Range. Can. Geotech. J., 40, 237-253.

RogAN, J., \& CHEN, D. (2004), Remote sensing technology for mapping and monitoring land-cover and land-use change. Prog. Plan., 61, 301-325.

Rogan, J. \& Yool, S. R. (2001), Mapping fire-induced vegetation depletion in the Peloncillo Mountains, Arizona and New Mexico. Int. J. Remote Sens. 22, 3101-3121.

SABINS, F. F. (1999), Remote sensing for mineral exploration. Ore Geol. Rev., 14, 157-183.

Schmidt, K. M., Roering, J. J., Stock, J. D., Dietrich, W. E., Montgomery, D. R. \& SCHAUB, T. (2001), The variability of root cohesion as an influence on shallow landslide susceptibility in the Oregon Coast Range. Can. Geotech. J., 38, 995-1024.

TsaI, F., Hwang, J.-H., ChEN, L.-C. \& Lin, T.-H. (2010), Post-disaster assessment of landslides in southern Taiwan after 2009 Typhoon Morakot using remote sensing and spatial analysis. Nat. Hazards Earth Syst. Sci., 10, 2179-2190.

TUCKER, C. J. (1979), Red and photographic infrared linear combinations for monitoring vegetation. Remote Sens. Environ., 8, 127-150.

VohorA, V. K. \& Donoghue, S. L. (2004), Application of remote Sensing data to Landslide mapping in Hong Kong. Int. Arch. Photogr. Remote Sens. GIS, V, 489-494.

Whitworth, M. C. Z., Giles, D. P. \& Murphy, W. (2005), Airborne remote sensing for landslide hazard assessment: a case study on the Jurassic escarpment slopes of Worcestershire, UK. Q. J. Eng. Geol. Hydrogeol., 38, 285-300.

ZhANG, Z., Gong, H., ZhAO, W. \& ZHANG, Y. (2005), Application of remote sensing to study of landslide. In: IGARSS 2005 Proceesings, IEEE, 1546-1549. 